\title{
Cooperation and Environmental Responsibility as Positive Factors for Entrepreneurial Resilience
}

\author{
Tancredi Pascucci *(D), Brizeida Raquel Hernández-Sánchez (D) and José Carlos Sánchez-García (D)
}

check for

updates

Citation: Pascucci, T.; Hernández-

Sánchez, B.R.; Sánchez-García, J.C.

Cooperation and Environmental

Responsibility as Positive Factors for

Entrepreneurial Resilience.

Sustainability 2022, 14, 424. https:/ /

doi.org/10.3390/su14010424

Academic Editors: Jaana Seikkula-

Leino, Mats Westerberg, Priti Verma

and Maria Salomaa

Received: 22 November 2021

Accepted: 29 December 2021

Published: 31 December 2021

Publisher's Note: MDPI stays neutral with regard to jurisdictional claims in published maps and institutional affiliations.

Copyright: (C) 2021 by the authors. Licensee MDPI, Basel, Switzerland. This article is an open access article distributed under the terms and conditions of the Creative Commons Attribution (CC BY) license (https:// creativecommons.org/licenses/by/ $4.0 /)$.
Department of Social Psychology and Anthropology, Salamanca University, 37005 Salamanca, Spain; brizeida@usal.es (B.R.H.-S.); jsanchez@usal.es (J.C.S.-G.)

* Correspondence: tancredipascucci@usal.es

\begin{abstract}
In this review, we study the state of entrepreneurial education as it applies to business resilience. We consider records over the last 20 years about entrepreneurial resilience that consider their social impact and focus on sustainability. The aim of the study was to determine whether an enterprise that stresses social impact and sustainability rather than profits could reinforce entrepreneurial resilience. The importance of this study is that it offers a more complex description of entrepreneurial resilience by connecting social and environmental sensitivity with a profit-oriented logic. We found a mild incremental rise in, first, the years of the 2000s and a jump by 2010. We then used VosViewer to create a cluster map from the record list of WOS, creating three clusters of: "education and sustainability", "entrepreneurship and social impact" and "innovation", and these three clusters were related to superior entrepreneurial resilience. This approach should be adopted in real time to be able to adapt to socio-economic crises, adopting a functional approach based on cooperativeness and awareness of complexity.
\end{abstract}

Keywords: sustainability; resilience; social impact; empowerment

\section{Introduction}

Crises in the last 20 years and throughout the 20th century have reached international proportions, often based on economic triggers. For example, two world wars occurred as a consequence of political and economic expansion, the Great Depression followed the Wall Street (NY, USA) crash of 1929, the 1973 petroleum crisis, the capitalist re-invention of former Soviet republics following the fall of the Berlin Wall, the Great Recession of 2007-2009 and, more recently, the COVID-19 recession as a consequence of the pre-existing vulnerability of socio-economic systems around the world, which led to the chaotic management of the flow of goods and people around the world [1,2]. These events stressed the need for Entrepreneurship Education (EE) to equip new and existing entrepreneurs with the managerial and entrepreneurial skills to manage similar difficulties and prevent similar crises in the future. A firm's survival depends on its ability to withstand difficulties, and it can be defined as "resilient" if it can adapt positively without altering its mission. [3-6]. "Resilience" is a term borrowed from Civil Engineering, which defines a material that has good resistance under pressure, is also used in Individual Psychology to define good adaptation during difficulties and has similarly been adopted in Management Science to define a "resistant" organization that can survive without significant impairment during international crises [7-9]. Not every business organization is resilient, and those that are are not at risk of being eliminated by a sort of economic Darwinian selection. EE is a discipline that began in 1947 to train new entrepreneurs to rebuild world economies after the war and received increasing attention during the 1980s, when universities began offering courses to train future entrepreneurs $[10,11]$ and create entrepreneurial research in the U.S. and Europe and then also in Asia [12].

International markets are prone to unpredictable events that can negatively influence a business, be they political, financial, environmental, technological, health-related or 
cultural. These can significantly affect consumer behavior, reducing the enterprise's earnings [13-19], but we cannot adopt a fatalistic view of the economy, whereby we renounce the responsibility to prevent similar, unexpected events or, at least, to buffer their negative consequences on markets and economic activity. Following a liberal logic, especially after the fall of the Berlin Wall and the conflict between capitalist and communist countries, many entrepreneurs followed an aggressive business strategy based on saving resources and maximizing profits without considering workers' rights, ecosystem balance or community needs [20-23]. This has impaired societies and the environment. For example, an entrepreneur who is entirely oriented toward profit maximization is not motivated to create a bond with the area where the enterprise operates; instead, they exploit the community's workforce, raw materials or strategic position [24], and the capital generated is sent elsewhere, leaving the community that invested in this activity impoverished. Sometimes, the environment in which these communities live become polluted, and they suffer socio-economic distress [25-27]. In contrast, some projects offer an alternative entrepreneurial model based not only on economics, but also on innovative strategies and social aspects of the area in which they operate [28-31], also involving some integrated models of the stakeholder theory [32]. An entrepreneurial organization cannot consider itself to be an isolated institution, considering that it has a precise community context, even if it operates across different regions [33]. This aggressive and hypercompetitive strategy does not consider the importance of cooperation [34,35], which requires a coordinated approach, even in Entrepreneurship, where different institutions and organizations have a functional approach in order to reach a common goal. The approach of cooperativeness first emerged at the end of the 1980s [36], and there are some interesting studies concerning this approach [37-39]. We considered the importance of sensibility for environmental responsibility where an enterprise, even a small business, adopts an approach aiming to reduce the impact of its activity in terms of pollution or territorial alteration. In this case, we cite ecological intelligence [40] and community psychology [41,42], both of which must be considered so as to improve entrepreneurial performance. Future entrepreneurs must also be trained to consider these factors, as well as the social impact in terms of community wellness, including terms of employment, social cohesion, a sense of community and community empowerment [43-45]. It is not just an ethical question because an enterprise that acts responsibly will be appreciated by the community, which may lead to stronger partnerships $[3,5,25,28,37]$. In the next section, we describe our hypothesis for conducting a literature review in relation to the coexistence of multiple factors, such as earnings and environmental and social sustainability, to reinforce entrepreneurship organization and then describe this scientific literature with state-of-the-art cluster mapping that defines its various components.

This study, designed to overturn Fisher's Separation Theorem [46,47], sought records in which entrepreneurial organizations merged their profit motive with both social and environmental aspects to become more resilient and robust $[4,5,8,26]$. Entrepreneurship Education should equip entrepreneurs with not only the right skills, but should also motivate them to improve the world by extending beyond simple profit accrual. In this case, it is important to reinforce the social function, and in this work, we define this as a pro-social and collaborative attitude characterized by a sustainable strategy, positive social impact and a cooperative entrepreneurial approach that reinforces the empowerment of communities in which the organization operates $[6,7,26,36,38]$.

\section{Materials and Methods}

For this review, we studied records from the last 20 years on entrepreneurial education that reinforce entrepreneurial resilience and survival, expecting that most would focus on sustainability and social sensitivity. To conduct this analysis, we used the following Boolean string: "(entrepreneur and education)" AND "(social and impact or resilience)" AND "(sustainability)". We searched the literature between 2000 and 2020, without limitations in relation to area, type of record or language; however, the most prevalent language was 
English. We decided on a wide selection because we noticed that this was a recent and uncrowded line of research, and we wanted to select a significant number of records in order to generate a satisfying review and cluster analysis. For this review, we stated an ambitious social function that involved all three aspects. We verified that there would be a more abundant record selection if we considered EE only from the sustainability, social impact or empowerment points of view. This is not just a choice governed by a practical need, but has the goal of evidencing that social, sustainability and entrepreneurial performance and resistance are not mutually exclusive domains.

Due to the fact that we opted for a restricted definition of our interest area, including different aspects contributing to a "virtuous" entrepreneur that aims to satisfy all three missions of social, ecological and economic goals, our record selection was poor, but specific, with just 16 excluded records that were defined as not pertinent. These records mostly involved a type of organization that is not dedicated to a sustainable and/or a social mission.

We used three databases on 26 August 2021-SCOPUS (https: / / www-scopus-com. ezproxy.usal.es/search/form.uri? display=basic\&zone=header\&origin=\#basic), WOS (https: / /www.webofscience.com/wos/alldb/basic-search) and EBSCO (https: / /web-s-ebscohostcom.ezproxy.usal.es / ehost/ search/advanced?vid=2\&sid=b763d2d8-f1f6-4ffa-90af-8eb724 1e75a $8 \% 40$ redis)—for record mapping and then VosViewer to analyze a list of records extrapolated from WOS, the platform from which most records were excluded due to a lack of relevance. We used the PRISMA Statement [48] to represent our records, as demonstrated in the selection chart provided in Figure 1.

Following the PRISMA checklist, we catalogued the title, abstract, keywords and type of study for each record. After the duplicates were removed, we excluded another group of records that mainly focused on financial aspects, history, university educational strategies, medical treatments, entrepreneurial orientation, philosophy, pedagogical strategies and blended education. This selection process aimed to be highly specific, uniting different domains for a holistic overview, instead of separating aspects related to, for example, sustainability, social impacts or Entrepreneurship Education, thereby differentiating itself from other reviews that are broader and more difficult to analyze than this record selection process. After this strict selection process, we chose the database with the most records for cluster mapping, which was WOS. 


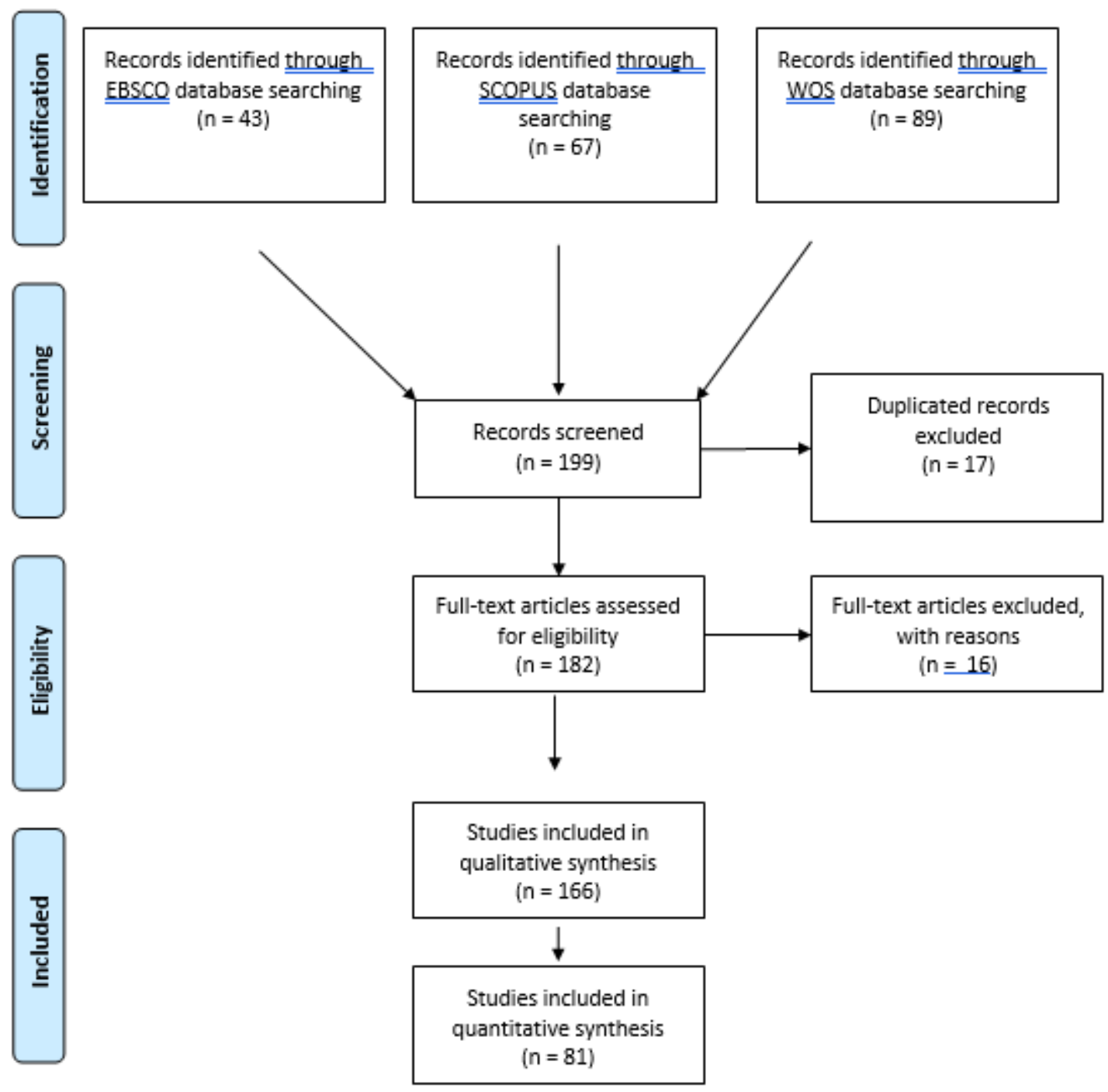

Figure 1. PRISMA Statement chart representation.

\section{Results}

Interest in the topic of entrepreneurial education to foster organizational resilience has emerged recently, judging from the evolution of the number of records in the last 20 years (Figure 2). Beginning in 2000, there was discontinuous and poor production of work on the subject, with a mild increase during the economic crisis of 2007-2009 and a jump after that. We hypothesized that this world crisis provided an important lesson to entrepreneurial organizations: that an approach that was totally focused on profits was dysfunctional and dangerous for economic stability $[13,17,18,20]$.

Most of the contributions originated from the U.S. and UK, confirming a primacy trend found in many other research lines. We appreciate, as illustrated in Figure 3, that, unexpectedly, the third most active country was Spain, followed by India, Canada and Malaysia, demonstrating that there was also interest from European and Asian countries. We think that that the need to reinforce research on Entrepreneurship Resilience is related to the actual economic crisis unfolding across the globe. We could hypothesize that this urgency is changing the research trend, passing from developed and English-speaking countries to a new group of developed and non-English speaking countries. 


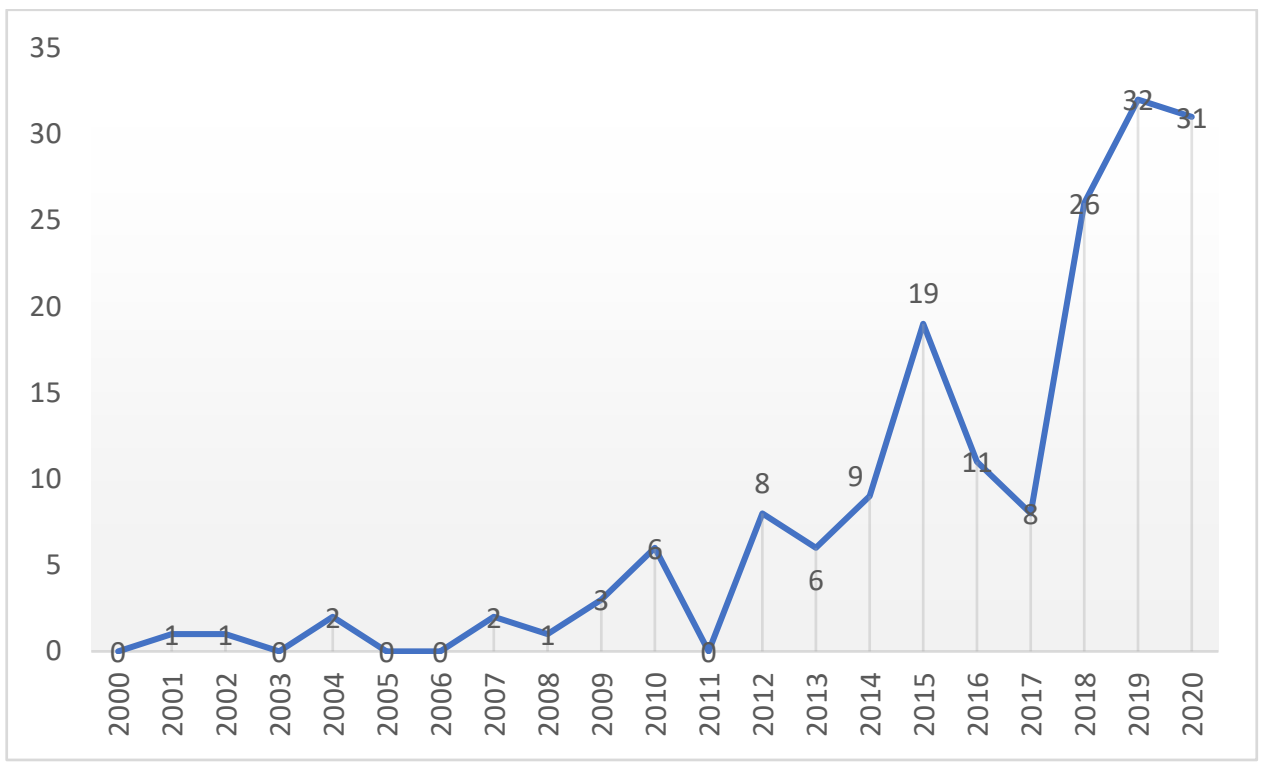

Figure 2. Publication progression during the last 20 years.

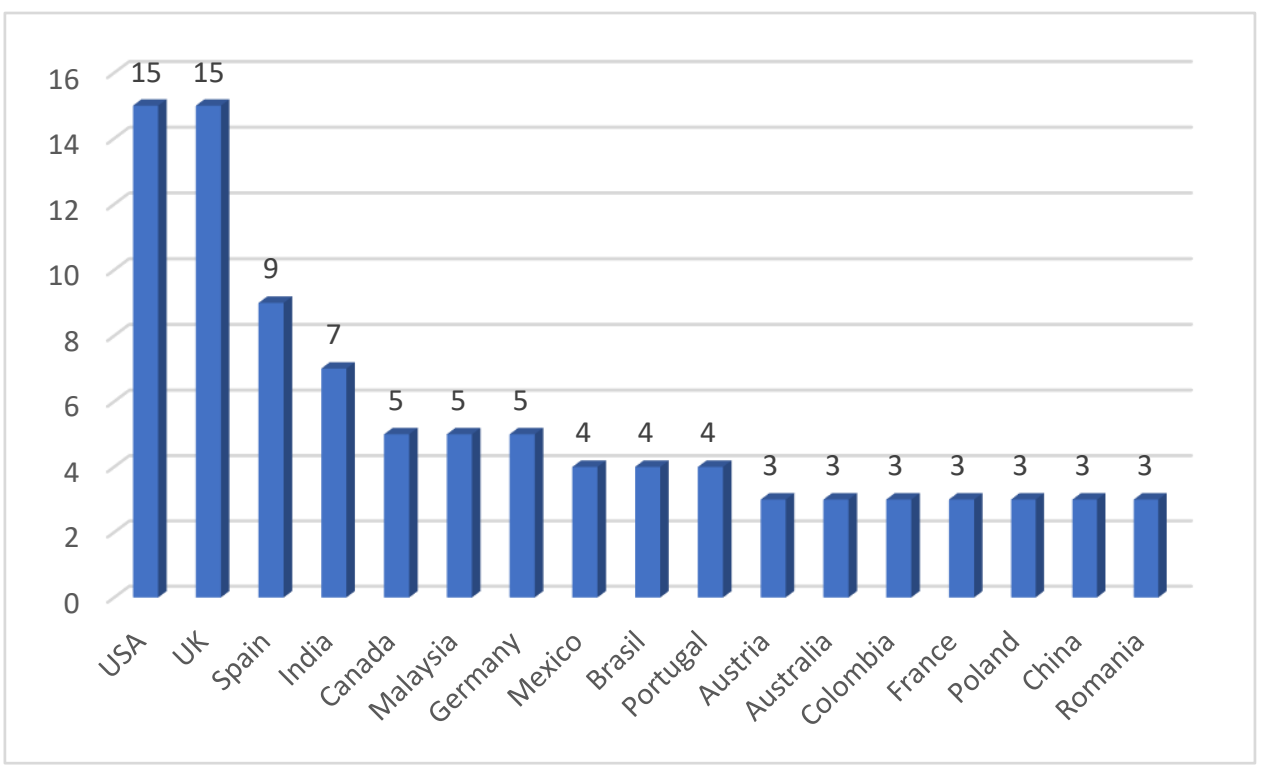

Figure 3. Representation of most productive countries for record publishing.

As previously stated, this is an emerging topic, and only a small number of authors have published papers on it. As represented in Table 1 they come from both developed and developing countries that have an h-index between 4 and 20. We do not yet have a large enough number of publications to hypothesize that the results are significantly generalizable, but we can observe that most of these authors are from developing countries. Some of them work together, forming research lines concerning sustainable entrepreneurship $[49,50]$. 
Table 1. Representation of authors with more than 2 publications in our record.

\begin{tabular}{|c|c|c|c|c|}
\hline No. & Author & Actual Affiliation & H-Index & Prevailing Research Area \\
\hline 2 & Matzenbacher D.E. & $\begin{array}{l}\text { Universidade Federal do Rio } \\
\text { Grande do Sul, Porto } \\
\text { Alegre, Brazil }\end{array}$ & 4 & $\begin{array}{l}\text { Environmental Sciences, Social Sciences, } \\
\text { Business Management and accounting }\end{array}$ \\
\hline 2 & Mets T. & Tartu Ulikool, Tartu, Estonia & 9 & $\begin{array}{l}\text { Business Management and Accounting, } \\
\text { Social Sciences, Computer Sciences }\end{array}$ \\
\hline 2 & Raudsaar M. & Tartu Elikool, Tartu, Estonia & 3 & $\begin{array}{l}\text { Business Management and Accounting, } \\
\text { Social Sciences, Environmental Sciences }\end{array}$ \\
\hline 2 & De Barcellos M.D. & $\begin{array}{c}\text { Universidade Federal do Rio } \\
\text { Grande do Sul, Porto } \\
\text { Alegre, Brazil }\end{array}$ & 20 & $\begin{array}{l}\text { Business Management and Accounting, } \\
\text { Environmental Sciences, Social Sciences }\end{array}$ \\
\hline 2 & Iyer V.G. & $\begin{array}{l}\text { University of Louisville, } \\
\text { Louisville, KY, USA }\end{array}$ & 14 & Neurosciences, Nursing, Psychology \\
\hline
\end{tabular}

Table 2 represents the most active journals. The first is Sustainability, which specializes in this area (in particular with regard to Environmental Sciences), but a variety of journals in countries, such as the U.S., UK, the Netherlands and Germany, have research areas that are quite varied, from social science to engineering.

Table 2. Representation of most productive journals.

\begin{tabular}{|c|c|c|c|}
\hline No. & Journals & H-Index & Research Area \\
\hline 16 & Sustainability & $85(\mathrm{Q} 1)$ & Environmental Sciences, Social Sciences, Energy \\
\hline 6 & $\begin{array}{c}\text { International Journal of Entrepreneurial } \\
\text { Behaviour and Research }\end{array}$ & $67(\mathrm{Q} 1)$ & Business, Management and Accounting \\
\hline 3 & $\begin{array}{c}\text { International Journal of Sustainability in } \\
\text { Higher Education }\end{array}$ & $59(\mathrm{Q} 2)$ & $\begin{array}{c}\text { Social Sciences, Education, Human factors } \\
\text { and Ergonomics }\end{array}$ \\
\hline 2 & $\begin{array}{l}\text { Smart Innovation Systems } \\
\text { and Technologies }\end{array}$ & $22(\mathrm{Q} 4)$ & Computer Sciences, Decision Sciences \\
\hline 2 & $\begin{array}{l}\text { International Journal of } \\
\text { Entrepreneurial Venturing }\end{array}$ & $17(\mathrm{Q} 3)$ & $\begin{array}{l}\text { Business and International Management, } \\
\text { Management of Technology and Innovation, } \\
\text { Strategy and Management }\end{array}$ \\
\hline 2 & Journal of Cleaner Production & $200(Q 1)$ & $\begin{array}{l}\text { Strategy Management, Renewanable Energy, } \\
\text { Industrial and Manufacturing Engineering }\end{array}$ \\
\hline 2 & Journal of Rural Studies & $104(Q 1)$ & Forestry, Development, Sociology \\
\hline
\end{tabular}

\section{Cluster Analysis}

If we had conducted a brief study on Entrepreneurship Education with just one component, such as "entrepreneur and education" AND "social and impact or resilience" or "entrepreneur and education" AND "sustainability", we would have had a much larger group of records; for example:

- "Entrepreneur * AND Education" AND "Social AND impact OR resilience" has 809 records on EBSCO, 700 on SCOPUS and 1229 on WOS;

- "Entrepreneur * AND Education" AND "Sustainability" has 578 records on EBSCO, 508 on SCOPUS and 552 on WOS.

Once we refined the list of records on WOS, which included all previous dimensions, we used VosViewer [51] to load this list to create an analysis that clustered different research areas related to this research line. We decided to use VosViewer for its graphical intuitive representation, whereby the most important keywords are located in the representation area. Cluster mapping is an important analysis technique that provides a graphical representation of research lines, where similar topics, summarized by their tracking keywords, are regrouped into wider categorizations in each thematic cluster. A map of 3 clusters with 11 items is represented in Figure 4. The most powerful keywords identified in this case are Sustainability (Link strength $=25$; Occurrence $=20$ ), Education (Link strength $=24$; 
Occurrence $=18$ ), Innovation (Link strength $=23$; Occurrence $=12$ ), Social Entrepreneurship $($ Link strength $=13$; Occurrence $=9)$ and Impact $($ Link strength $=11$; Occurrence $=7)$, with a relationship between them that reinforces the others in a holistic conception, whereby, for example, a Sustainability-centered approach is the goal for improving an Organization but can also act as a method by which to improve it.

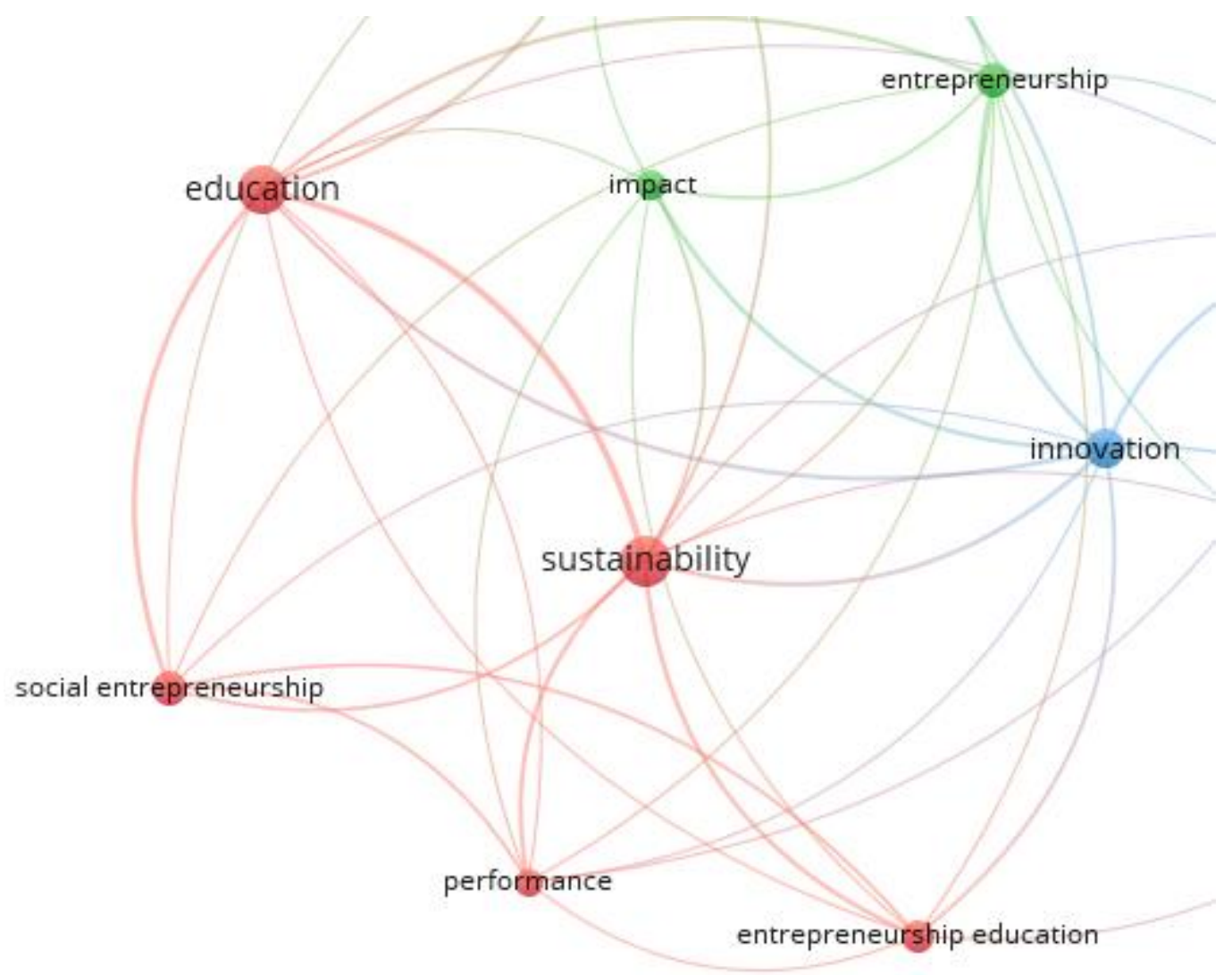

Figure 4. Cluster map of our research topic.

\subsection{Cluster 1: Education and Sustainability (5 Items)}

The first and most numerous cluster on Figure 5 (Education with link strength $=24$ and occurrence $=18$; Sustainability with link strength $=25$ and occurrence $=20$ ) occurs around two keywords concerning the training of future entrepreneurs with a sensitive, pro-environmental attitude [26,52-57]. In this cluster, entrepreneurial education [23,52-62] and performance appear because a well-formed entrepreneur has a higher performance level [6,63-65], which reinforces his or her empowerment [21,66]. This cluster also includes the social entrepreneurship keyword [31,67-69], an area distinguished from sustainability $[24,44,52,53,70,71]$, although it has some common points regarding socio-economic interdependence [54,72]. 


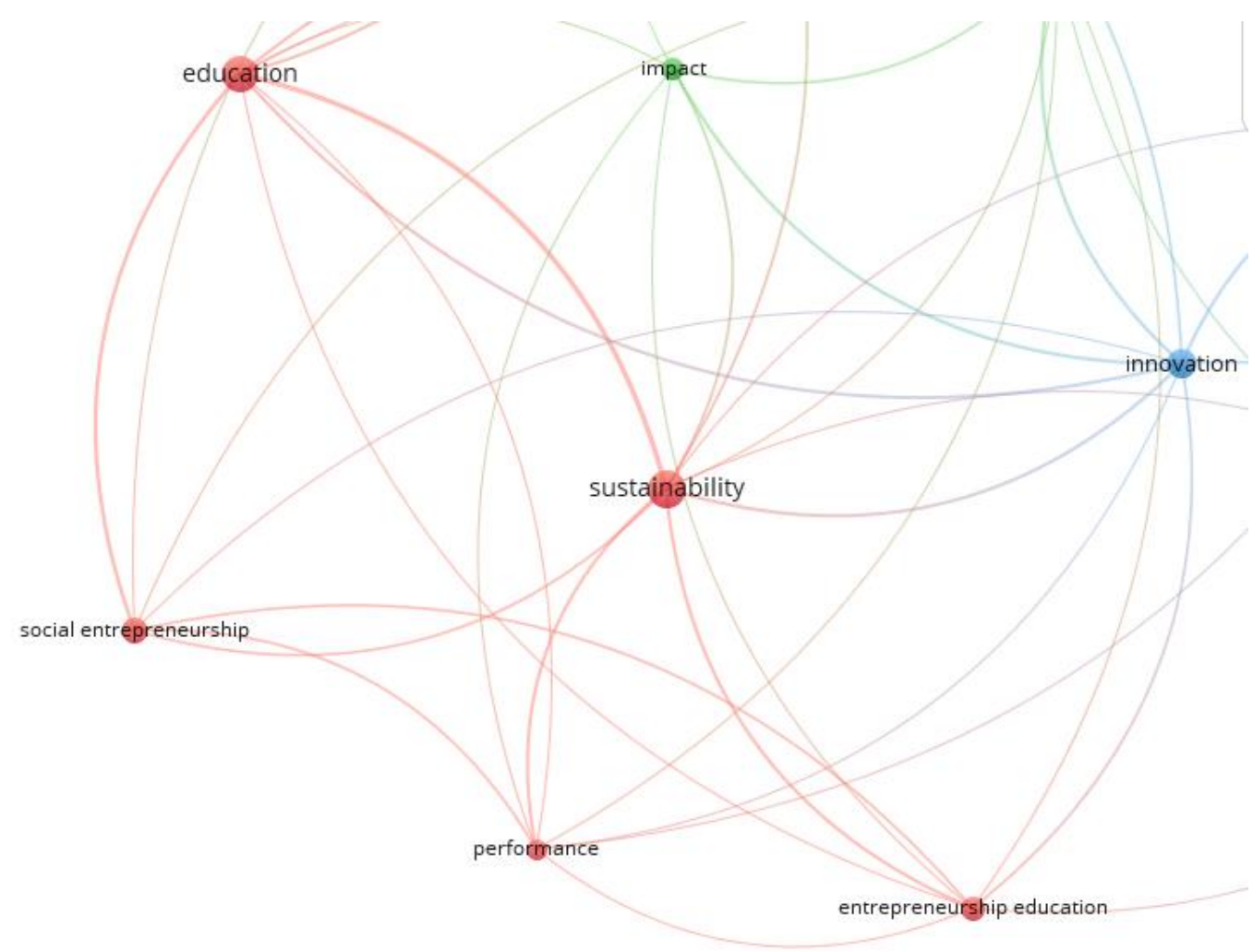

Figure 5. Representation of Cluster 1 map.

\subsection{Cluster 2: Entrepreneurship and Social Impact (3 Items)}

This cluster on Figure 6 focuses more on the management [17,20,26,28,68,73-75] of this kind of enterprise [75]. Following the previously cited stakeholder theory $[7,58,76]$, these kinds of organizations pursue an entrepreneurial strategy to consider the wider social impact $[49,58,70,75,77,78]$, thereby reinforcing entrepreneurial resilience through stronger community approval (Entrepreneurship with link strength $=16$ and occurrence $=10$; Social Impact with link strength $=11$ and occurrence $=7$ ), which would help it to survive in a crisis.

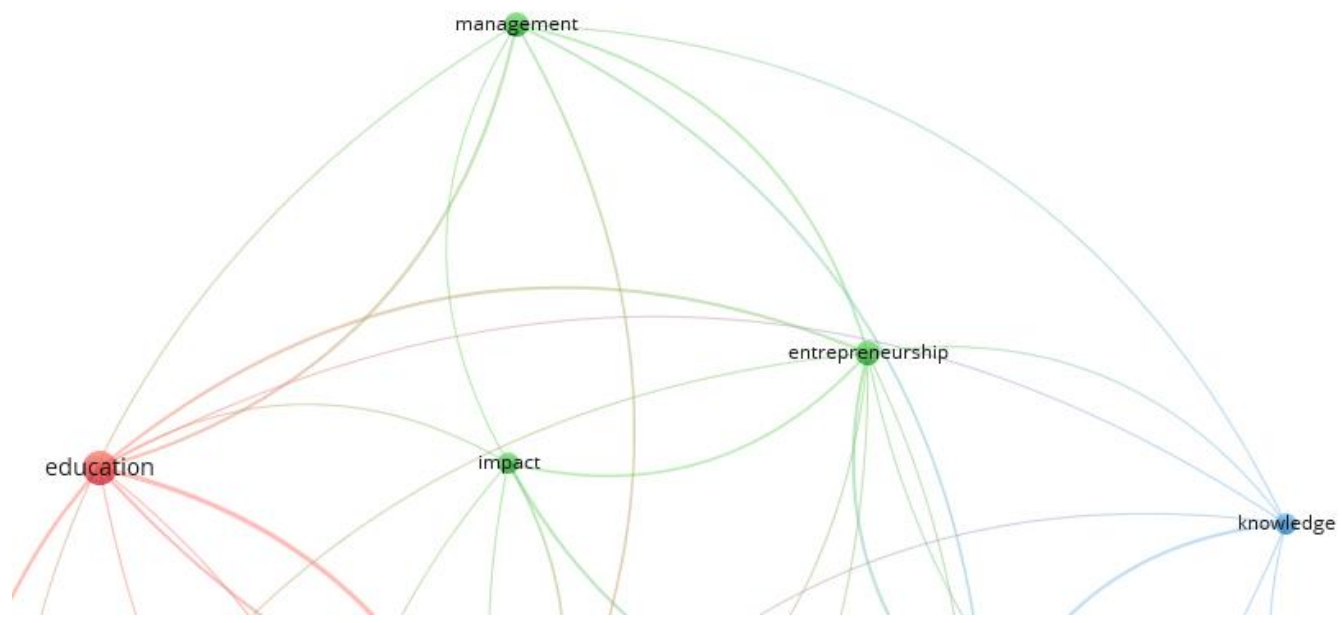

Figure 6. Representation of Cluster 2 map.

\subsection{Cluster 3: Innovation (3 Items)}

An important aspect in Figure 7 of a functional education is the incorporation of innovative points of view and protocols (Innovation with link strength $=23$ and occurrence $=12$; 
Knowledge with link strength $=9$ and occurrence $=7$ ) into a mindful entrepreneurial strategy $[34,79-84]$. This can be realized through an exchange of knowledge $[11,54,60]$ with university institutions $[11,59,62,85]$, which creates the right combination between theory and practice.

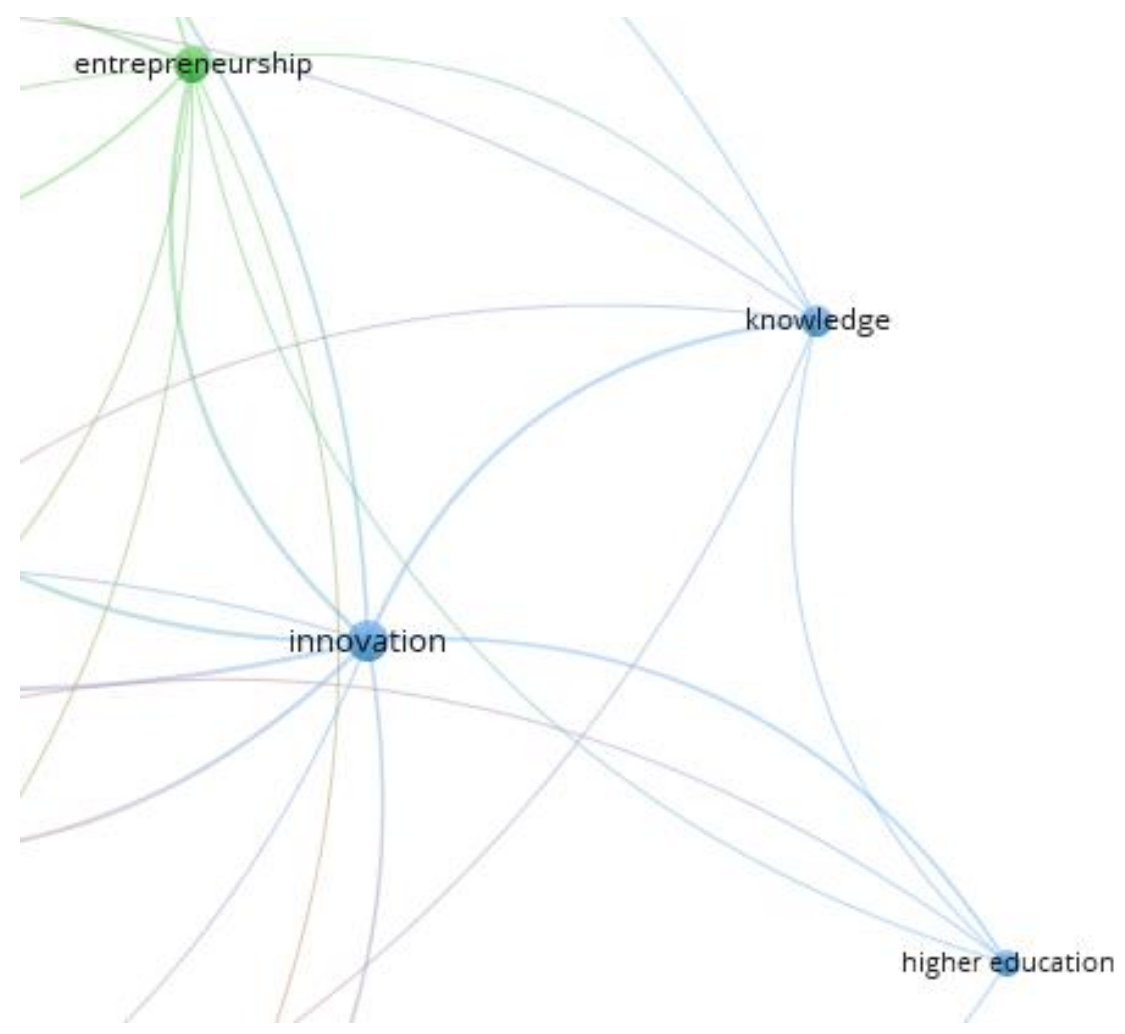

Figure 7. Representation of Cluster 3 map.

Figure 8 clearly shows the main point of view of this review. The keyword "Sustainability" is, in this case, the most powerful keyword (with a total link of 25 and 20 co-occurrences) that recalls the other cluster keywords. This means that, over the last 20 years, Sustainability has become a core theme, considering the relatively recent formation of the Kyoto Protocol and other green initiatives that have called attention to the pollution emergency and the need for sustainable development [86-89]. This need does not find appreciation in countries that have so far stressed the urgency of a solid economy without considering the environmental cost $[90,91]$; however, in countries trying to integrate environmental approaches within economic and social planning [91-95], the sustainable approach is not seen as antithetical to economic and social development.

Figure 9 regroups the main items that have been characterized for their cluster strength and co-occurrences. Social Impact, Innovation and Sustainability are the most important keywords in this study, which is founded on intersections between these three domains in which they merge and combine to create a new area of research. The main area of this study is defined by Entrepreneurship Education, which connects these three aspects, namely, Innovation, Sustainability and Social Impact; there are some intersections between the Innovation and Social Impact areas, as defined by Social Entrepreneurship, which combine a managerial approach of traditional enterprise with the need to satisfy the social function $[31,46,47,61,96]$; the intersection between Innovation and Sustainability is located in Higher Education due to a proper use of knowledge [7,11,54,59,60,62,85]; Entrepreneurship Resilience is related to a combination between Social Impact and Sustainability, where the Organization is strategy oriented so as to consider the interdependence of environmental and social factors in relation to a business $[5,7,10,17]$. 


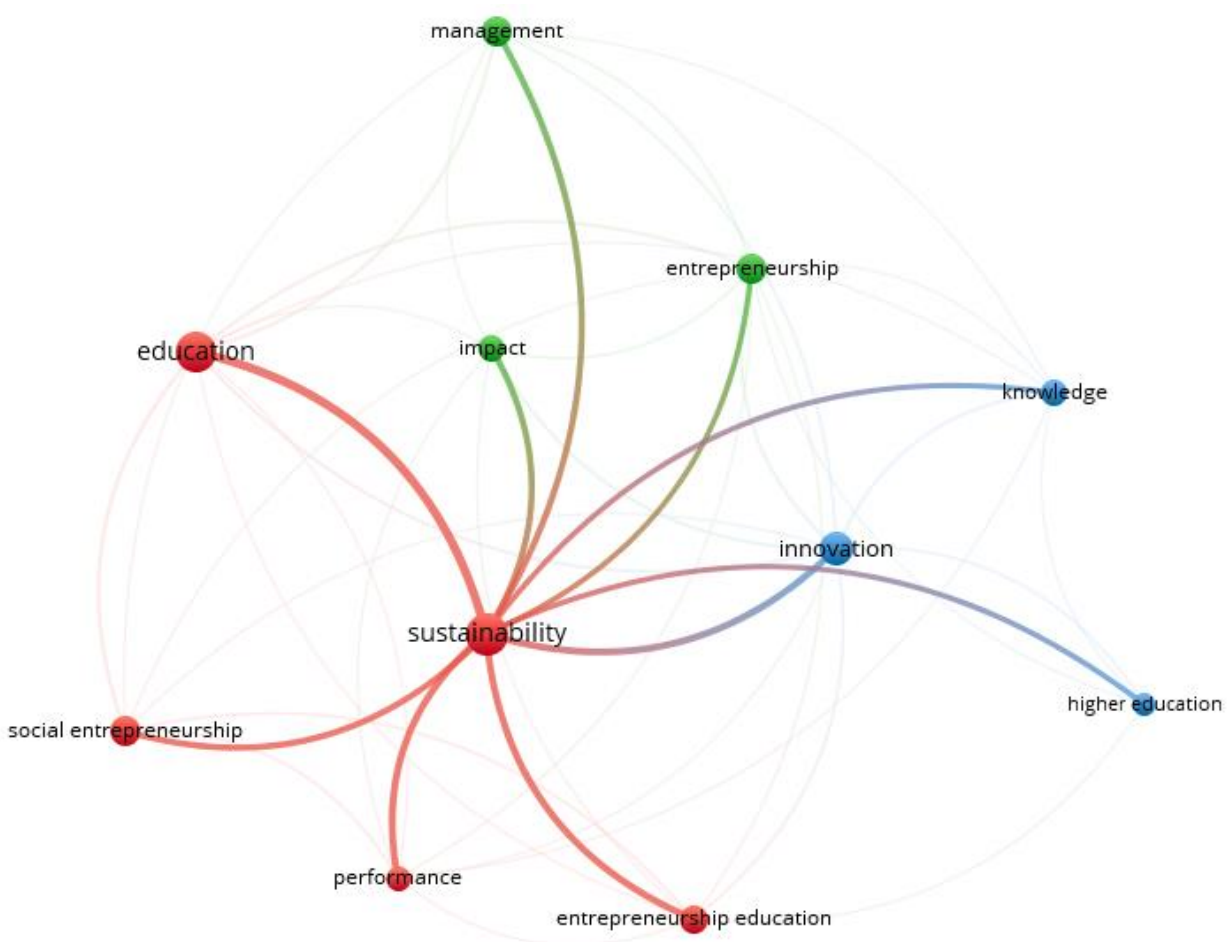

Figure 8. Representation of a cluster focused on sustainability.

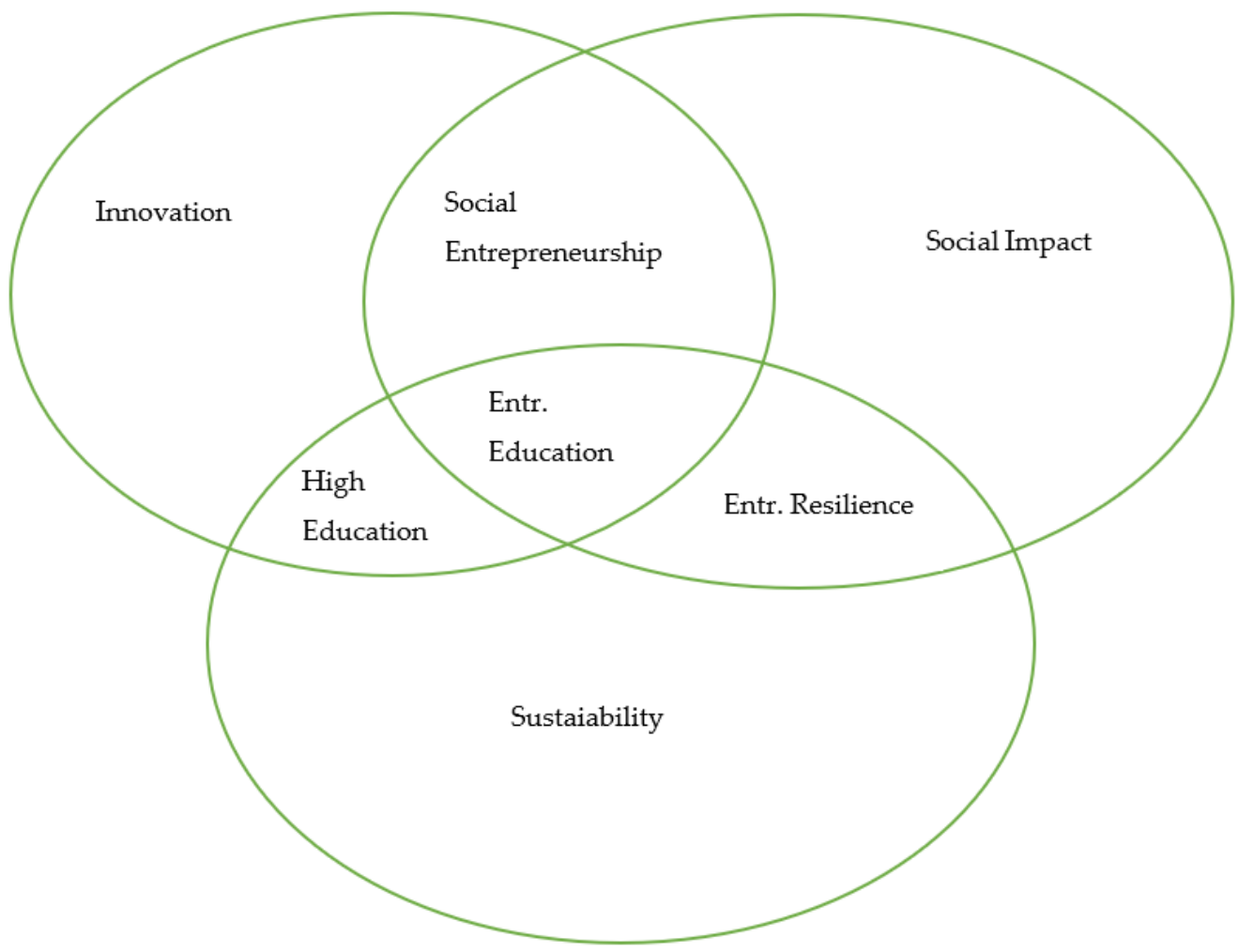

Figure 9. Representation of main keywords.

\section{Discussion and Conclusions}

A quick database search for entrepreneurial education "AND" resilience "OR" social impact "OR" sustainability produced many records, with a total of just under 1000 on SCOPUS. We chose to consider these keywords together because they are often considered 
independently. For example, an enterprise that focuses on societal change alone may neglect the environmental aspects, as was observed during a Boolean search of entrepreneurial education "AND" resilience "OR" social change "AND NOT" sustainability and vice versa when social change OR resilience was excluded. This trend of neglecting certain aspects is often encouraged, especially for ideological reasons. This was verified in some districts that refused to shut down their industrial structures because they feared the loss of jobs $[6,11,75,81,97]$. Despite this, innovations in technology are now making possible an effective industrial conversion that saves jobs and worker identities and preserves a sense of community as well as the environment [26,60,98-101]. From this point of view, entrepreneurial resilience must be considered as the result of different components. Mutual interaction reinforces the organization, in contrast to the traditional entrepreneurial philosophy in which a firm must maximize earnings to avoid failure $[4,5,15,19]$, act as an individual $[21,22,102,103]$ and avoid cooperation $[74,75,80,87,88,93,94,96]$.

Recently, COVID-19 has exposed the illusion of medical and institutional invulnerability in the most privileged countries as social disparity, individualism, mental problems, economic instability and social injustice have been exacerbated. Consequently, humankind has had to rediscover the values of honesty, generosity, courage and foresight. The rejection of neo-liberal management provides the possibility of understanding the interdependence between world and market events [104-112]; adopting this mode of entrepreneurship, we will live in a better place-one in which an organization gains trust from the community and the entrepreneurial ecosystem in which it operates and receives help in return $[6,36]$.

In the future, Entrepreneurship Education will have to negotiate some fundamental strategic challenges, such as training new entrepreneurs to use innovative strategies based on the skilled use of technology [29,99]; promoting managerial competences $[59,68,89]$ to consider social [25,27-31,33,40,113] and environmental aspects [3,52,113]; and using electronic communication to facilitate learning [99]. EE has to adapt to different economic areas, including developing countries such as China, which is a complex and populous country with a high level of economic activity, consumption and pollution $[84,95,114]$, but also in countries currently managing their economic transition $[113,115,116]$. There is a need for entrepreneurs to use wisdom in management strategies despite their fear of failure [33,116] and the risk of losing profits. [4,5,25,30]. A sustainable entrepreneurial strategy can assist in sectors such as "slow food" or agriculture [94,95], but also in those that have slow growth, and can provide a level of stability that can help them to resist a crisis $[4,5,18,26,33,74]$. The stakeholder theory underlines how important an ethical approach is for management, not only for business interest, but also for an interdependent socio-economic network, especially during world crises such as pandemics $[9,19,109]$. With this work, we state the urgent need for a "wealthy" entrepreneurial ecosystem $[6,110]$.

This study suffers from some limitations, such as the use of a cluster analysis using just the WOS database, and the lack of precise restriction criteria for record selection. Perhaps it is too early to define a precise research line due to the significant dispersion among authors' contributions in this area, but we are fairly certain that it is a promising and growing topic for future research, especially after the end of the pandemic, as there will be a clear need to rebuild and re-organize interactions among people, organizations and communities, starting with the resilient organizations that survive the crisis.

It is tempting and easier to employ a reductive approach and focus on just one or two objectives when starting a business. This focus could just be to make money while neglecting civil rights and exploiting the environment, creating social distress and pollution as a result. Furthermore, it is important to underline, in this case, the relevance of the stakeholder theory, in which a responsible act performed by a restricted group of people encourages collective action to improve the world within and outside of an institutional framework $[7,63,92]$. We can also set a double objective, combining economic and social goals, economic and green goals, or social and green goals, while neglecting the third aspect. Even if the Gross Domestic Product (GDP) is sometimes considered to be an incomplete criterion to evaluate a country's economic performance [15], the World 
Bank (N.H., U.S.A.) shows that the annual growth of GDP for all countries in the world and-with the exception of China, a large country experiencing continuous growth-of most economic superpowers is decreasing, and we hypothesize that the current economic strategy, based primarily on an individualistic short-term planning strategy, should be reconsidered [103]. These approaches are often encouraged by ideology, but this can be a superficial approach that does not appreciate the entrepreneurial ecosystem complexity. In this case, the enterprise will fail, lose its resilience and collapse because it will not have a functional, long-term strategy. There is a need for entrepreneurial education to avoid the superficial, short-sighted approach. In this case, it is important to consider recent contributions from Nobel Prize researchers, which encourage the consideration of emotional triggers in economic behaviors $[117,118]$, restructuring a dysfunctional belief about economic-rational infallibility.

In line with the Community Psychology Paradigm [43-45], Entrepreneurship Education could reinforce concern for Sustainability and Social Impacts with regard to the territory, developing a sense of empowerment among citizens and Entrepreneurial Organizations, which could foster a functional attitude with a spontaneous initiative and/or through Institutional Intervention provided by the Government, which could encourage people, services and communities to adopt social functions, as represented in Figure 10. It suggests that organizational change for entrepreneurs comes from the top, via direct Statal-Institutional intervention, combined with change at the bottom. This requires the modification of the personal attitudes of entrepreneurs so that they are not just led by Institutions, but so that they also have a genuine, intrinsic motivation for creating a business organization that has a social function. Entrepreneurs should also be well informed about the interdependence of these worlds and their events and actions. [7,25,28,31]

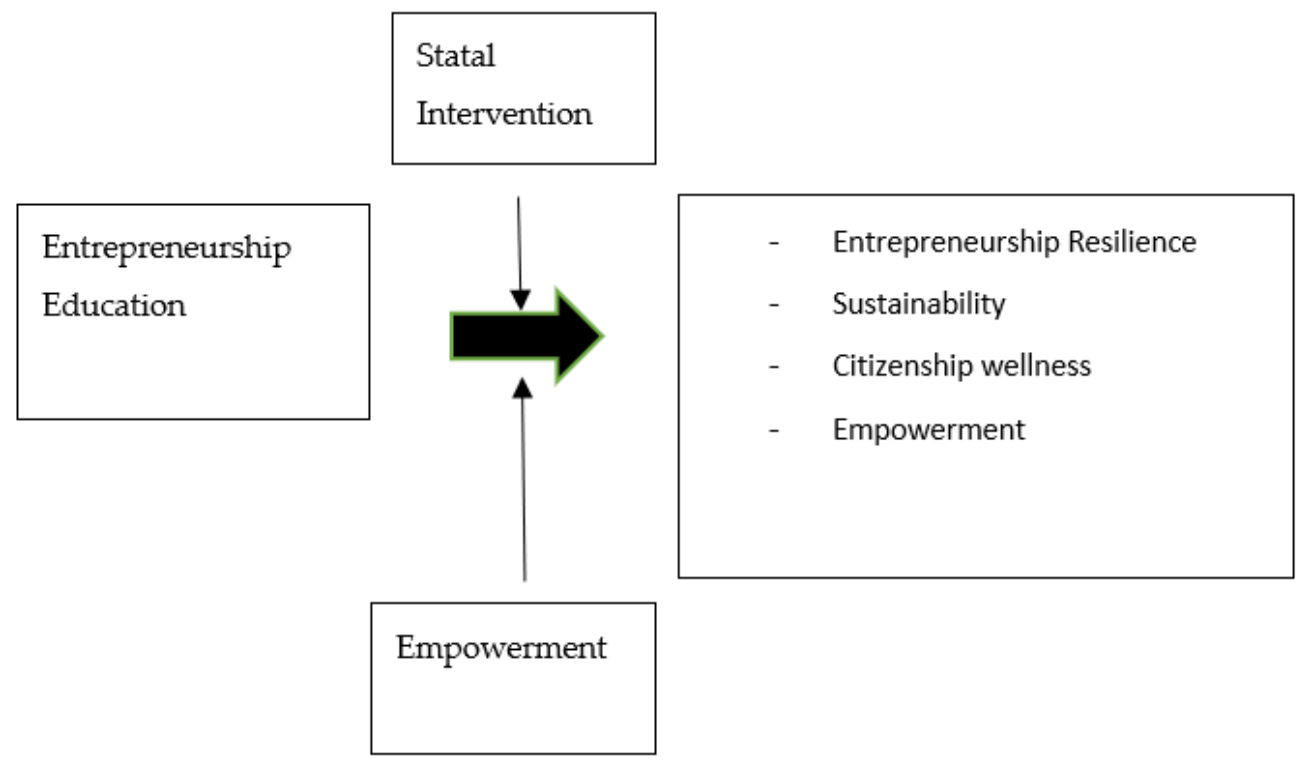

Figure 10. Representation of positive factors for Sustainability and Organizational Resilience.

The empowerment of a community could be considered in this case both as a result of and a positive contributor to providing resilience, wellness and sustainability within communities $[21,50,55]$. In the future, we hope to use similar instruments for cluster mapping, such as SciMAT, CitNetExplorer and Sci2Tool [119-121] and databases such as SSCI [122] or EBSCO, following the example of other papers [123], with a different approach regarding co-occurrence and co-citations. 


\begin{abstract}
Author Contributions: All authors have contributed equally to the development of this article. All authors have read and agreed to the published version of the manuscript.
\end{abstract}

Funding: This research received no external funding.

Institutional Review Board Statement: Not applicable.

Informed Consent Statement: Not applicable.

Conflicts of Interest: The authors declare no conflict of interest.

\title{
References
}

1. Diaz, C.M.G.; Sanchez, G.A.C. Analysis of the Financial Intermadiation on the stage of the XX and XXI Centuries Crisis. Sophia-Educ. 2011, 7, 106-128.

2. Mehediyev, A. The oil factor in the history of Azerbaijan. Vopr. Istor. 2018, 10, 138-144.

3. Krehebiel, T.C.; Gorman, R.F.; Erkson, O.H.; Louks, O.L.; Johnson, P.C. Advancing ecology and economics through a businessscience synthesis. Ecol. Econ. 1999, 14, 183-186. [CrossRef]

4. Liebenau, J.; Alleman, J. Network resilience and its regulatory inhibitors. Glob. Econ. Digit. Soc. 2004, 379-392.

5. Rose, A.; Liao, S.Y. Modeling regional economic resilience to disasters: A computable general equilibrium analysis of water service disruptions. J. Reg. Financ. 2004, 45, 75-112. [CrossRef]

6. Geng, Y.; Cote, R. Diversity in industrial ecosystems. Int. J. Sustain. Dev. World Ecol. 2007, 14, 329-335. [CrossRef]

7. Santoro, G.; Bertoldi, G.; Giachino, C.; Candelo, E. Exploring the relationship between entrepreneurial resilience and success: The moderating role of stakeholders' engagement. J. Bus. Res. 2020, 119, 142-150. [CrossRef]

8. Renko, M.; Bullough, A.; Saeed, S. How do Resilience and Self-Efficacy relate to entrepreneurial intentions in countries with varying degrees of fragility? A six-country study. Int. Small Bus. J. Res. Entrep. 2021, 39, 130-156. [CrossRef]

9. Zighan, S.; Abualqumboz, M.; Dwaikat, N.; Alkalha, Z. The role of Entrepreneurial orientation in developing SMEs resilience capabilities throught COVID-19. Int. J. Entrep. Innov. 2021. [CrossRef]

10. Pittaway, L.; Cope, J. Entrepreneurship education: A systematic review of the evidence. Int. Small Bus. J. 2007, 25, 479-510. [CrossRef]

11. Mascarenhas, C.; Marques, C.; Galvão, A.R.; Santos, G. Entrepreneurial university: Towards a better understanding of past trends and future directions. J. Enterprising Communities People Places Glob. Econ. 2017, 11, 316-338. [CrossRef]

12. $\mathrm{Wu}, \mathrm{Y} . \mathrm{C} . J . ; \mathrm{Wu}, \mathrm{T}$. A decade of entrepreneurship education in the Asia Pacific for future directions in theory and practice. Manag. Decis. 2017, 55, 1333-1350. [CrossRef]

13. Girard, S.; Agundez, J.A.P. The effects of the oyster mortality crisis on the economics of the shellfish farming sector: Preliminary review and prospects from a case study in Marennes-Oleron Bay (France). Mar. Policy 2014, 48, 142-151. [CrossRef]

14. Park-Barjort, R.R. Samsung: An original case of knowledge transfer in economic organizations. Enterp. Hist. 2014, 75, 91-101.

15. Cerrato, D.; Alessandri, T.; Depperu, D. Economic crisis, acquisition and Firm Performance. Long Range Plan. 2016, 42, 171-185. [CrossRef]

16. Ulgen, F. Samsung: Financial development, economic crises and emerging market economies Financial Development. In Economic Crises and Emerging Market Economies; Routledge: London, UK, 2016; pp. 1-244.

17. Angel, K.; Menendez-Plans, C.; Orgaz Guerrero, N. Risk management: Comparative analysis of systematic risk and effect of the financial crisis on US tourism industry: Panel data research. Int. J. Contemp. Hosp. Manag. 2018, 30, 1920-1938. [CrossRef]

18. Hyz, A. SME Finance and the Economic Crisis: The Case of Greece; Routledge: London, UK, 2019; pp. 1-119.

19. Golubeva, O. Firms' performance during the COVID-19 outbreak: International evidence from 13 countries. Corp. Gov. Int. J. Bus. Soc. 2021, 21, 1011-1027. [CrossRef]

20. Michalski, T. Radical innovation through corporate entrepreneurship from a Competence-Based Strategic Management perspective. Int. J. Manag. Pract. 2006, 2, 22-41. [CrossRef]

21. Mahato, R.V.; Ahluwalia, S.; Walsh, S.T. The diminishing effect of VC reputation: Is it hypercompetition? Technol. Forecast. Soc. Chang. 2018, 133, 229-237. [CrossRef]

22. Vaisman, E.D.; Podshivalova, M.V. Assessment of small industry resistance to the hypercompetition threats in regions. Econ. Reg. 2018, 14, 1232-1245. [CrossRef]

23. Cooke, P. Economic globalisation and its future challenges for regional development. Int. J. Technol. Manag. 2003, 26, 401-420. [CrossRef]

24. Bellandi, M.; Carloffi, A. District internationalisation and trans-local development. Entrep. Reg. Dev. 2008, 20, 517-532. [CrossRef]

25. Smith, D.C.; James, C.D.; Griffiths, M.A. Co-brand partnerships making space for the next black girl: Backlash in social justice branding. Psychol. Mark. 2021, 38, 2314-2326. [CrossRef]

26. Surya, B.; Suriani, F.; Menne, F.; Abubakar, H.; Idris, M.; Rasyidi, E.S.; Remmang, H. Community empowerment and utilization of renewable energy: Entrepreneurial perspective for community resilience based on sustainable management of slum settlements in Makassar city, Indonesia. Sustainability 2021, 13, 3178. [CrossRef]

27. Uduji, J.I.; Okolo-Obasi, E.N.; Asongu, S.A. Oil extraction in Nigeria's Ogoniland: The role of corporate social responsibility in averting a resurgence of violence. Resour. Policy 2021, 70, 101927. [CrossRef] 
28. Pless, N.M.; Maak, T.; Stahl, G.K. Promoting corporate social responsibility and sustainable development through management development: What can be learned from international service learning programs? Hum. Resour. Manag. 2012, 51, 873-903. [CrossRef]

29. Urbano, D.; Guerrero, M.; Ferreira, J.J.; Fernandes, C.I. New technology entrepreneurship initiatives: Which strategic orientations and environmental conditions matter in the new socio-economic landscape? J. Technol. Transf. 2019, 44, 1577-1602. [CrossRef]

30. Eggers, F. Masters of disasters? Challenges and opportunities for SMEs in times of crisis. J. Bus. Res. 2020, 116, 199-208. [CrossRef]

31. Sirine, H.; Andadari, R.K.; Suharti, L. Social Engagement Network and Corporate Social Entrepreneurship in Sido Muncul Company, Indonesia. J. Asian Financ. Econ. Bus. 2020, 7, 885-892. [CrossRef]

32. Argandoña, A. El bien Común; IESE Business School, Universidad de Navarra: Barcelona, Spain, 2011.

33. Naradda Gamage, S.K.; Ekanayake, E.M.S.; Abeyrathne, G.A.K.N.J.; Prasanna, R.P.I.R.; Jayasundara, J.S.M.B.; Rayapakshe, P.S.K. A review of global challenges and survival strategies of small and medium enterprises (SMEs). Economies 2020, 8, 79. [CrossRef]

34. Chuah, S.H.; Hoffmann, R.; Ramasamy, B.; Tan, J.H.W. Is there a spirit of Overseas Chinese Capitalism? Small Bus. Econ. 2016, 47, 1095-1118. [CrossRef]

35. Crick, J.M. Incorporating coopetition into the entrepreneurial marketing literature: Directions for future research. J. Res. Mark. Entrep. 2019, 21, 19-36. [CrossRef]

36. Carsrud, A.L.; Olm, K.W.; Thomas, J.B. Predicting entrepreneurial success: Effects of multi-dimensional achievement motivation, levels of ownership, and cooperative relationships. Entrep. Reg. Dev. 1989, 1, 237-244. [CrossRef]

37. Levine, S.S.; Preitula, M.J. Open collaboration for innovation: Principles and performance. Organ. Sci. 2014, 25, 1414-1433. [CrossRef]

38. Kimuli, S.N.L.; Orobia, L.; Sabi, H.M. Sustainability intention: Mediator of sustainability behavioral control and sustainable entrepreneurship. World J. Entrep. Manag. Sustain. Dev. 2020, 2, 81-95. [CrossRef]

39. Srikaliman, S.; Wardana, L.W.; Ambarwati, D.; Sholhin, U.; Shobrin, L.A.; Fajarah, N.; Wibowo, A. DO Creativity and Intellectual Capital matter for SME sustainability? The role of competitive advantage. J. Asian Financ. Econ. Bus. 2020, 7, 397-408. [CrossRef]

40. Goleman, D. Ecological Intelligence: The Hidden Impacts of What We Buy; Broadway Books: New York, NY, USA, 2010.

41. Rappaport, J. In Praise of Paradox. A Social Policy of Empowerment over Prevention. Am. J. Community Psychol. 1981, 1, 1-25. [CrossRef] [PubMed]

42. Francescato, D.; Tomai, M.; Solimeno, A. Lavorare e Decidere Meglio in Organizzazioni Empowering ed Empowered; Franco Angeli: Milan, Italy, 2008.

43. Mulyono, S.E.; Sutarto, J.; Malik, A.; Loretha, A.F. Community Empowerment in Entrepreneurship development based on local potential. Int. J. Innov. Creat. Chang. 2020, 11, 271-283.

44. Rocha, H.; Kunc, M.; Audretsch, D.B. Clustersm Economic Performance and social cohesion: A system dynamics approach Reg. Stud. 2020, 54, 1098-1111. [CrossRef]

45. Rojikinnor, R.; Gani, A.J.A.; Saleh, H.; Amin, F. Empowerment throught good Governance and Public Service Quality. J. Asian Financ. Econ. Bus. 2020, 7, 491-497. [CrossRef]

46. Wempe, B. Understanding the Separation Thesis; precision after the decimal point? A response to Joakim Sandberg. Bus. Ethics Q. 2008, 18, 549-553. [CrossRef]

47. Burger-Helmchen, T. Entrepreneurial Organizations. In Encyclopedia of Creativity, Invention, Innovation and Entrepreneurship; Cavannis, E.G., Ed.; Springer: New York, NY, USA, 2013.

48. Mother, D.; Liberati, A.; Tetzlaff, J.; Altman, D.G. Preferred reporting items for systematic reviews and meta-analyses: The PRISMA statement. PLoS Med. 2009, 6, e1000097.

49. Matzembacher, D.E.; Raudsaar, M.; De Barcellos, M.D.; Mets, T. Sustainable entrepreneurial process: From idea generation to impact measurement. Sustainability 2019, 11, 5892. [CrossRef]

50. Matzembacher, D.E.; Raudsaar, M.; De Barcellos, M.D.; Mets, T. Business models' innovations to overcome hybridity-related tensions in sustainable entrepreneurship. Sustainability 2020, 12, 4503. [CrossRef]

51. Waltman, L.; Van Eck, V.J.; Noyons, E.C.M. A unified approach to mapping and clustering of bibliometric networks. J. Infometrics 2010, 4, 629-635. [CrossRef]

52. Badulescu, D.; Badulescu, A.; Bac, D.P.; Saveanu, T.; Florea, A.; Perticas, D. Education and Sustainable Development: From theoretical interest to specific behaviours. J. Environ. Prot. Ecol. 2017, 18, 1698-1705.

53. Moon, C.; Walmsley, A.; Apostolopoulos, N. Sustainability and Entrepreneurship Education. A Survey of 307 UN HESI signatories. In Proceedings of the 13th European Conference On Innovation And Entrepreneurship (ECIE 2018), Aveiro, Portugal, 20-21 September 2018; pp. 498-506.

54. Rios, M.M.M.; Herremans, I.M.; Wallace, J.E.; Althouse, N.; Landsale, D.; Presseur, M. Strengthening sustainability leadership competencies through university internships. Int. J. Sustain. High. Educ. 2018, 19, 739-755. [CrossRef]

55. Anderson, O. Education provides a foundation for Community Empowerment IEEE Smart Village Programs Teach Residents Job, Technical and Business, Skills. IEE Syst. Man Cybern. Mag. 2019, 5, 42-46. [CrossRef]

56. Yu, C.W.M.; Man, T.W.Y. The sustainability of enterprise education: A case study in Hong Kong. Educ. Train. 2007, 49, 138-152.

57. Urbaniec, M. Sustainability-oriented competencies in entrepreneurship education: Insights from an empirical study on Polish students. Int. Entrep. Rev. 2018, 4, 399-411. 
58. Galvao, A.R.; Marques, C.S.E.; Ferreira, J.J.; Braga, V. Stakeholders' role in entrepreneurship education and training programmes with impacts on regional development. J. Rural. Stud. 2020, 74, 169-179. [CrossRef]

59. Sanchez-Hernandez, M.I.; Gallardo-Vazquez, D.; Pajuelo-Moreno, M.L. University Social Responsibility: A Modelling Framework for Student Base Analysis. In Proceedings of the 9th International Technology, Education and Development Conference, Madrid, Spain, 2-4 March 2015; pp. 2523-2530.

60. Sandoval, F.; Garcia, F. Por La Senda De Un Futuro Sustentable. Propuestas Y Acciones Con Responsabilidad Social. In Sustainability in University Education: A Challenge for a Comprehensive Education in the Faculty of Economy and Business of the University of Chile; Universidad de Santiago de Chile: Santiago, Chile, 2016; pp. 557-568.

61. Shier, M.L.; Van-Du, B. Framing curriculum development in social work education about social enterprises: A scoping literature review. Soc. Work. Educ. 2018, 37, 995-1014. [CrossRef]

62. Martinez-Campillo, A.; Sierra-Fernandez, M.D.; Fernandez-Santos, Y. Service-Learning for Sustainability Entrepreneurship in Rural Areas: What Is Its Global Impact on Business University Students? Sustainability 2019, 11, 5296. [CrossRef]

63. Al Mamun, A.; Ibrahim, M.D.; Bin Yusoff, M.N.H.; Fazal, S.A. Entrepreneurial Leadership, Performance, and Sustainability of Micro-Enterprises in Malaysia. Sustainability 2018, 10, 1591. [CrossRef]

64. Iqbal, Q.; Ahmad, N.H.; Halim, H.A. Insights on entrepreneurial bricolage and frugal innovation for sustainable performance Bus. Strategy Dev. 2021, 4, 237-245. [CrossRef]

65. Özdemirci, A. Corporate entrepreneurship and strategy process: A performance based research on Istanbul market. ProcediaSocial and Behavioral Sciences. In Proceedings of the 7th International Strategic Management Conference, Paris, France, 30 June-2 July 2011; Volume 24, pp. 611-626.

66. Radovic-Markovic, M.; Zizanovic, B. Fostering Green Entrepreneurship and Women's Empowerment through Education and Banks' Investments in Tourism: Evidence from Serbia. Sustainability 2019, 11, 6826. [CrossRef]

67. Nga, J.K.H.; Shamuganathan, G. The Influence of Personality Traits and Demographic Factors on Social Entrepreneurship Start Up Intentions. J. Bus. Ethics 2010, 95, 259-282.

68. Starnawska, M. Determining Critical Issues In Social Entrepreneurship Education. In Proceedings of the 6th International Conference Innovation Management, Entrepreneurship And Sustainability (IMES 2018), Prague, Czech Republic, 31 May-1 June 2018; pp. 1014-1024.

69. Tam, H.L.; Asmoah, E.; Chan, A.Y.F. Developing Social Entrepreneurship as an Intervention to Enhance Disadvantaged Young People's Sense of Self-Worth and Career Competence in Hong Kong. Appl. Res. Qual. Life 2021, 19, 1-30. [CrossRef]

70. Rus-Casas, C.; Eliche-Quesada, D.; Aguilar-Pena, J.D.; Jimenez-Castillo, G.; La Rubia, M.D. The Impact of the Entrepreneurship Promotion Programs and the Social Networks on the Sustainability Entrepreneurial Motivation of Engineering Students. Sustainability 2020, 12, 4935. [CrossRef]

71. Chatterjee, S.; Duttagupta, S.; Upadhyay, P. Sustainability of microenterprises: An empirical analysis. Benchmarking Int. J. 2018, 25, 919-931. [CrossRef]

72. Masouman, A.; Harvie, C. Regional economic modelling through an embedded econometric-inter-industry framework. Reg. Stud. 2018, 52, 1237-1249. [CrossRef]

73. Iyer, V.G. Strategic Environmental Assessment (SEA) Process towards Sustainable Construction Management Development for the Electrical, Automation and Mechanical Engineering Construction Industries Business excellence achievements. In Proceedings of the 2018 3rd International Conference On Electrical, Automation and Mechanical Engineering (EAME 2018), Xi'an, China, 24-25 June 2018.

74. Grant, J.H. Advances and Challenges in Strategic Management. Int. J. Bus. 2007, 12, 11-31.

75. Arshad, R.; Noor, A.H.R.; Yahya, A. Human Capital and Islamic-Based Social Impact Model: Small Enterprise Perspective. Procedia Econ. Financ. 2015, 31, 510-519. [CrossRef]

76. Morelli, A.; Taramelli, A.; Bozzeda, F.; Valentini, E.; Colangelo, M.A.; Cueto, Y.R. The disaster resilience assessment of coastal areas: A method for improving the stakeholders' participation. Ocean. Coast. Manag. 2021, 241, 105867. [CrossRef]

77. Beeri, I.; Gottlieb, D.; Izhaki, I.; Eshet, T.; Cohen, N. The Impact of Training on Druze Entrepreneurs' Attitudes Towards and Intended Behaviors Regarding Local Sustainability Governance: A Field Experiment at the Mount Carmel Biosphere Reserve. Sustainability 2020, 12, 4584. [CrossRef]

78. Rok, B.; Kulik, M. Circular start-up development: The case of positive impact entrepreneurship in Poland. Corp. Gov. Int. J. Bus. Soc. 2020, 21, 339-358. [CrossRef]

79. Zhu, L.; Li, M.; Metaa, N. Financial Risk Evaluation Z-Score Model for Intelligent IoT-based Enterprises. Inf. Processing Manag. 2021, 58, 102692. [CrossRef]

80. Iyer, V.G. Strategic Environmental Assessment (SEA) Process for Green Materials and Environmental Engineering Systems towards Sustainable Development-Business Excellence Achievements. In Proceedings of the 4th International Conference on Green Materials and Environmental Engineering (GMEE), Beijing, China, 28-29 October 2018.

81. Zdonek, I.; Mularczyk, A.; Polock, G. The idea of corporate social responsibility in the opinion of future managers-Comparative research between Poland and Georgia. Sustainability 2021, 13, 7045. [CrossRef]

82. Buil, M.; Aznar, J.P.; Galiana, J.; Rocafort-Marco, A. An Explanatory Study of MBA Students with Regards to Sustainability and Ethics Commitment. Sustainability 2016, 8, 280. [CrossRef] 
83. Rooney, D.; McKenna, B. Should the Knowledge-Based Economy be a Savant or a Sage? Wisdom and Socially Intelligent Innovation. Prometheus 2005, 23, 307-323. [CrossRef]

84. Markopoulos, E.; Staggl, A.; Gann, E.L.; Vanharanta, H. Beyond Corporate Social Responsibility (CSR): Democratizing CSR Towards Environmental, Social and Governance Compliance. In International Conference on Applied Human Factors and Ergonomics; Springer: Cham, Switzerland, 2021; Volume 276, pp. 94-103.

85. Contreas-Pacheco, O.E.; Calderon, A.B. Leadership in Clusters: A Missing Link in the Academic Knowledge Corpus. Rev. Virtual Univ. Catol. Norte 2017, 50, 183-203.

86. Kolmas, M. Japan and the Kyoto Protocol: Reconstructing 'proactive' identity through environmental multilateralism. Pac. Rev. 2017, 30, 462-477. [CrossRef]

87. Sedita, S.R.; Ozeki, T. Path renewal dynamics in the Kyoto kimono cluster: How to revitalize cultural heritage through digitalization. Eur. Panning Stud. 2021. [CrossRef]

88. Salameh, M.T.B.; Alraggad, M.; Harasheh, S.T. The water crisis and the conflict in the Middle East. Sustain. Water Resour. Manag. 2021, 7, 69. [CrossRef]

89. Sassenrath, G.F.; Halloram, J.M.; Archer, D.; Raper, R.L.; Hendrickson, J.; Vadas, P.; Hanson, J. Drivers Impacting the Adoption of Sustainable Agricultural Management Practices and Production Systems of the Northeast and Southeast United States. J. Sustain. Agric. 2010, 34, 680-702. [CrossRef]

90. Han, Q.; Jennings, J.E.; Liu, R.J.; Jennings, P.D. Going home and helping out? Returnees as propagators of CSR in an emerging economy. J. Int. Bus. Stud. 2019, 50, 857-872. [CrossRef]

91. Filley, T.R.; Li, M.L.; Zhuang, J.; Yu, G.R.; Sayler, G.; Ouyang, Z.Y.; Han, X.G.; Zhang, X.G.; Jiang, G.B.; Zhou, C.H.; et al. Bi-national research and education cooperation in the US-China EcoPartnership for Environmental Sustainability. J. Renew. Sustain. Energy 2015, 7, 041512. [CrossRef]

92. Rousseau, J.F. Does carbon finance make a sustainable difference? Hydropower expansion and livelihood trade-offs in the Red River valley, Yunnan Province, China. Singap. J. Trop. Geogr. 2017, 38, 90-107. [CrossRef]

93. Stroud, D.; Fairbrother, P.; Evans, C.; Blake, J. Skill development in the transition to a 'green economy': A 'varieties of capitalism' analysis. Econ. Labour Relat. Rev. 2014, 25, 10-27. [CrossRef]

94. DeLind, L.B. Where have all the houses (among other things) gone? Some critical reflections on urban agriculture. Renew. Agric. Food Syst. 2015, 30, 3-7. [CrossRef]

95. Hosseinina, G.; Ramezani, A. Factors Influencing Sustainable Entrepreneurship in Small and Medium-Sized Enterprises in Iran: A Case Study of Food Industry. Sustainability 2016, 8, 1010. [CrossRef]

96. Freeman, R.E. Business ethics at the Millenium. Glob. Ethics Bus. 2000, 10, 169-180. [CrossRef]

97. Castro, M.P.; Scheede, C.R.; Zermeno, M.G.G. The Impact of Higher Education on Entrepreneurship and the Innovation Ecosystem: A Case Study in Mexico. Sustainability 2019, 11, 5597. [CrossRef]

98. Ares, J. Estimating pesticide environmental risk scores with land use data and fugacity equilibrium models in Misiones, Argentina. Agric. Ecosyst. Environ. 2004, 103, 45-58. [CrossRef]

99. Calvo, S.; Lyon, F.; Morales, A.; Wade, J. Educating at Scale for Sustainable Development and Social Enterprise Growth: The Impact of Online Learning and a Massive Open Online Course (MOOC). Sustainability 2020, 12, 3247. [CrossRef]

100. Bernard-Hernandez, P.; Ramirez, M.; Mosquera-Montoya, M. Formal rules and its role in centralised-diffusion systems: A study of small-scale producers of oil palm in Colombia. J. Rural. Stud. 2021, 83, 215-225. [CrossRef]

101. Ajayi, C.O. The effect of Microcredit on rural household livelihood: Evidence from women micro entrepreneurs in Oyo State, Nigeria. Sci. Pap. Ser. Manag. Econ. Eng. Agric. Rural. Dev. 2016, 16, $29-36$.

102. McKenna, B. Wisdom, Ethics and the Postmodern Organisation. In Handbook on the Knowledge Economy; Rooney, D., Hearn, G., Ninan, A., Eds.; Edward Elgar: Gloucestershire, UK, 2005; pp. 37-53.

103. Burrows, S. Precarious work, neo-liberalism and young people's experiences of employment in the Illawarra region. Econ. Labour Relat. Rev. 2013, 24, 380-396. [CrossRef]

104. Billet, A.; Dufays, S.; Friedel, S.; Staessens, M. The resilience of the cooperative model: How do cooperatives deal with the COVID-19 crisis? Strateg. Chang. 2021, 30,99-108. [CrossRef]

105. Hayter, C.S. Toward a strategic view of higher education social responsibilities: A dynamic capabilities approach. Strateg. Organ. 2018, 16, 12-34. [CrossRef]

106. Parris, D.L.; McInnis-Bowers, C. Business Not as Usual: Developing Socially Conscious Entrepreneurs and Intrapreneurs. J. Manag. Educ. 2017, 41, 687-726. [CrossRef]

107. Yildrim, K.; Onder, M. Collaborative Role of Metropolitan Municipalities in Local Climate Protection Governance Strategies: The Case of Turkish Metropolitan Cities. J. Environ. Assestment Policy Manag. 2019, 21, 1950006. [CrossRef]

108. Yin, R.; Yin, G.; Li, L. Assessing China's ecological restoration programs: What's been done and what remains to be done? Integr. Assess. China's Ecol. Restor. Programs 2009, 45, 442-453.

109. Chocholab, P.; Tapachai, N. Organizational resilience of SMEs in the Czech Republic: An exploratory analysis. In Proceedings of the ICABR 2015: X. International Conference On Applied Business Research, Madrid, Spain, 14-18 September 2015; pp. 395-417.

110. Larsson, M.; Milestad, R.; Hahn, T.; Von Oelreich, J. The resilience of a sustainability entrepreneur in the Swedish food system. Sustainability 2016, 8, 550. [CrossRef] 
111. Notman, O. The value of short-term training for Russian managers in the context of economic crisis. In Proceedings of the 10th International Days of Statistics and Economics, Prague, Czech Republic, 8-10 September 2016; pp. 1344-1352.

112. Ahmad, M. Does underconfidence matter in short-term and long-term investment decisions? Evidence from an emerging market. Manag. Decis. 2021, 59, 692-709. [CrossRef]

113. Bednar, P.; Danko, L.; Smekalova, L. Coworking spaces and creative communities: Making resilient coworking spaces through knowledge sharing and collective learning. Eur. Plan. Stud. 2021. [CrossRef]

114. Deszy, S.; Miclaus, C.; Rizescu, N.; Nicu, M. Industrial sites and past pollution problems. Environ. Eng. Manag. J. 2004, 3, 861-869.

115. Žebrytè, I.; Fonseca-Vasquez, M.; Hartley, R. Emerging economy entrepreneurs and open data: Decision-making for natural disaster resilience. J. Small Bus. Strategy 2019, 29, 36-46.

116. Chlopecky, J.; Rolcikova, L.; Kratochvil, M. Decision making influence of some macroeconomic factors concerning prospective sales of silicon carbide. In Proceedings of the 15th International Multidisciplinary Scientific Geoconference SGEM 2015, Albena, Bulgaria, 18-24 June 2015; pp. 171-178.

117. Kahneman, D.; Tversky, A. Heuristics and Biases: The Psychology of Intuitive Judgement; Cambridge University Press: Cambridge, UK, 2002.

118. Tahler, R.H. Misbehaving: The Making of Behavioral Economics.; W. W. Norton \& Company: New York, NY, USA, 2015.

119. Sci2 Team. Science of Science (Sci2) Tool; Indiana University (USA) and SciTech Strategies: Albuquerque, NM, USA, 2009.

120. Cobo, M.J.; Lòpez-Herrera, A.G.; Herrera-Viedma, E.; Herrera, F. SciMat: A new Science mapping analysis software tool. J. Am. Soc. Inf. Sci. Technol. 2012, 63, 1609-1630. [CrossRef]

121. Van Eck, N.J.; Waltman, L. CitNetExplorer: A new software tool for analyzing and visualizing citation networks. J. Informetr. 2014, 8, 802-823. [CrossRef]

122. Torres-Pruñonosa, J.; Plaza-Navas, M.A.; Dìez-Martinf, F.; Beltran-Cangròs, A. The Intellectual Structure of Social and Sustainable Public Procurement Research: A Co-Citation Analysis. Sustainability 2021, 13, 774. [CrossRef]

123. Torres-Prunonosa, J.; Plaza-Navas, M.A.; Diez-Martin, C. The source of Knowledge of the Economic and Social Value in Sport Industry Research: A co-citation Analysis. Front. Psychol. 2020, 11, 629951. [CrossRef] [PubMed] 